\title{
MULTIMEDIA INTERFACE AS A SUPPORT TOOL FOR LOGISTICS DECISION-MAKING
}

\author{
Iwona Grabara ${ }^{1}$
}

\begin{abstract}
Growing complexity of problems of logistics management in enterprises and differentiation of the used applications without common database force businesses to search for solutions which facilitate the processes of logistics decision-making. One of the concepts proposed in this chapter is a design of decision-maker/logistics interface. Firstly, technologies of corporate portals were described, being a basis for ergonomic and useful interface. Next the properties typical of functional multimedia interface adapted to the logistics decision-makers' needs were listed. Further in the chapter, methodological assumptions for interface creation were made whereas the benefits brought by personalization of both form (in terms of topography, colours and arrangement of main components of the interface) and content were emphasized.
\end{abstract}

Key words: corporate portal, dynamic internet applications, graphical user interface model;

JEL codes: L82, G33

\section{Introduction}

One of the most often emphasized barriers to implementation of integrated logistics IT systems is lack of financial resources, particularly in small and medium businesses. According to the results of the conducted surveys and interviews [ Badania kwestionariuszowe i wywiady przeprowadzone przez autora w 124 przedsiębiorstwach różnej branży i wielkości w środkowo południowej Polsce], almost $100 \%$ of the entities, regardless of the branch and size, have access to the Internet, ca $60 \%$ have their own internal Intranet network, whereas $15 \%$ own Extranet connections. Only few enterprises declare optimal use of these technologies for more advance services, supporting logistics activity within the organization. They include, among other things, creation of new distribution channels, sales of goods and services, use of banking and financial services supporting logistics operations within the entity or use of internal networks for facilitation of the processes of document flow, collecting and management of logistic information in order to extend knowledge resources necessary for making all the logistics decisions. Therefore the need arises to manage logistics information throughout their whole life cycles; cheaper and more advanced telecom technologies come in to help.

Corporate portals play an increasingly significant role in the area of logistics management, being an integral part of the most essential systems of management, i.e. systems of information for managers and support for logistics decision-making. They affect the development of business entities towards extended enterprises, which should be understood as a whole logistics chain, from suppliers through transport and procurement companies to distribution itself, treated as a single comprehensive system (Pańkowska M., Sroka H (red.), 2002, s. 20), whereas previous monolithic systems will be ousted by a set of applications forming autonomous components. An opportunities for corporate portals originated from conventional intranet and instantaneous access to all necessary logistics information, generated both within a company and its environment arise.

${ }^{1}$ Czestochowa University of Technology,ig@ch.pl; 


\section{Interface}

Corporate Portal Technology as a Basis for Creation of Logistics Decision Makers'

The interface proposed in this study, as a tool for logistics decision-makers, based on WWW (World Wide Web), provides additional information for support of logistics management. They give fast and intuitive access to huge archive of multimedia documents stored at a variety of servers connected to the network dispersed throughout the world. In the beginning, this standard was used for exchange of information and data transfer.

Nowadays, through incessant development of technologies, WWW sites allow for communication between logistics specialists, deepening of the knowledge through newest information contained in scientific publications, files, software updates, making banking transactions, monitoring of account balance etc. (A.Małachowski, 2003, s.34.). In websites, similarly to other network services, a client-server model is used. WWW documents are written using XML (Extensible Markup Language) or HTML (HyperText Markup Language), which comprise hypertext documents coding and formatting using tags and elements.

Hypertext is an extended version of text format containing additional hyperlinks, being codes of HTML language, also known as markup tags. They define the structure of the created document, contain information about the method of displaying a website on the screen and they link keywords or phrases to other documents, allowing for presentation of the interrelated information. A counterpart for graphical hypertexts are hypermedia, which considerably simplify navigation and make it more attractive.

Surfing the websites is enabled by web browsers i.e. the software which interprets HTML code and are WWW server clients. This means that, through typing of any website address (URL), it communicates with any server which finds the requested website, sends it to web browser in the form of HTML code, where HTML tags are interpreted and displayed in the form of suitably formatted text and graphics for the selected website. The most popular tools of this type include.: Internet Explorer, Mozilla, Firefox, Opera, Netscape Navigator, Netscape Communicator.

Without having a particular WWW address, one can search for suitable information using search engines. The most frequently used tools of this type include Google, which searches both resources of Internet and corporate intranet (Google Desktop Search, Google Mini, Google Search Appliance) or Netsprint searching for websites in Polish Internet with opportunities to languagebased analysis and offering, for several years, its commercial version - Netsprint Intranet.

Growing popularity of computer networks among businesses, which was proved by the analysis of the conducted investigations, brings opportunities of use of them for optimization of logistics management, having great impact on the growth of the condition of the whole business entity. Comparison of the parameters of each computer network (Table 1) reveals that application of corporate portals combines advantages and reduces burdensome imperfectness of the networks within the companies. Thus a safe tool for access and management of all the resources within an organization and its environment appears.

Use of corporate portals brings opportunity to reach the most precious information for support of logistic decision-making. They are based on Web Server and Web Browser technologies using e.g. internet web browsers and other systems of searching which provide opportunities of authorization, used for verification of users and their authentication.

Presentation of the obtained information is realized by personalized interface based on IT technologies and tools defined as 'user friendly'. 
Table no. 1

\section{Fundamental differences between extranet, intranet and the Internet}

\begin{tabular}{|c|c|c|c|c|}
\hline & Extranet & Intranet & Internet & Corporate Portal \\
\hline $\begin{array}{l}\text { Type of network } \\
\text { and the area of } \\
\text { activity }\end{array}$ & $\begin{array}{l}\text { External, encompassing } \\
\text { the whole business, } \\
\text { preferential access from } \\
\text { the outside }\end{array}$ & $\begin{array}{l}\text { Internal, on the area of } \\
\text { the company, lack of } \\
\text { access from the outside }\end{array}$ & $\begin{array}{l}\text { External, global - } \\
\text { open to everyone }\end{array}$ & $\begin{array}{l}\text { Both external and } \\
\text { internal, encompasses } \\
\text { all the interested, } \\
\text { depending on } \\
\text { authorization level }\end{array}$ \\
\hline User type & $\begin{array}{l}\text { co-operators, } \\
\text { contractors, individual } \\
\text { customers with } \\
\text { particular authorization }\end{array}$ & $\begin{array}{l}\text { employees within a } \\
\text { particular organization } \\
\text { with certain } \\
\text { authorization }\end{array}$ & $\begin{array}{l}\text { all the persons } \\
\text { who search for } \\
\text { information }\end{array}$ & $\begin{array}{l}\text { verified and } \\
\text { authorized users who } \\
\text { belong to the } \\
\text { company and its } \\
\text { environment }\end{array}$ \\
\hline $\begin{array}{c}\text { Type of } \\
\text { information }\end{array}$ & $\begin{array}{l}\text { resources of corporate } \\
\text { information and } \\
\text { applications determined } \\
\text { by the assigned } \\
\text { authorization }\end{array}$ & $\begin{array}{l}\text { corporate information } \\
\text { resources and } \\
\text { applications } \\
\text { determined by } \\
\text { authorization of } \\
\text { employees }\end{array}$ & $\begin{array}{l}\text { all the easily- } \\
\text { accessible } \\
\text { information }\end{array}$ & $\begin{array}{l}\text { resources of } \\
\text { structural and non- } \\
\text { structural data } \\
\text { generated within a } \\
\text { company and its } \\
\text { environment and all } \\
\text { informational } \\
\text { resources and } \\
\text { applications available } \\
\text { according to } \\
\text { authorization }\end{array}$ \\
\hline Safety level & $\begin{array}{l}\text { totally protected } \\
\text { corporate information } \\
\text { and personal data of } \\
\text { employees }\end{array}$ & $\begin{array}{l}\text { totally protected } \\
\text { corporate information } \\
\text { and personal data of } \\
\text { employees }\end{array}$ & limited & $\begin{array}{l}\text { totally protected all } \\
\text { accessible } \\
\text { information }\end{array}$ \\
\hline
\end{tabular}

Source: own study

The name 'portal', originating from architecture nomenclature, expressing internet tools which open 'wide door to the land of unlimited resources of information and knowledge' ordered by means of hypermedia tools in a manner most user friendly, does not have unequivocal definition. It can be assumed that this tool presents catalogued information and gives users access to necessary information (Kisielnicki J, 2008, s.301). Enormous amount of knowledge, services and applications contained in corporate portal leads to specialization of them and thus to formation of a number of different types of portals, creating congestion and chaos within the company's network. It would be reasonable to create federated corporate portals used for realization of the architecture of the distributed tool applications, domain applications and others originating from different layers of organizational system in a company and thus for support of intelligent information management and, in consequence, resources of corporate knowledge. Portals with such functionalities are still at the stage of theoretical considerations.

Functionalities currently required from corporate portals have not been unequivocally defined yet. J.Gołuchowski (Gołuchowski J., 2005, s.187-188) divided them and placed in five fundamental groups, which is presented in Fig. 1.

First group is formed by personalization of presentation of knowledge, including such functionalities as content personalization and form personalization. includes:

Second group of functionalities connected with management of knowledge elements

- metadata management (taxonometry, categorization),

- knowledge management encompassing management of data and documents and integration of applications,

- knowledge updating, 
- searching for knowledge in the resources,

- querying/reporting and analysis of knowledge by means of specialized applications e.g. Business Intelligence Systems.

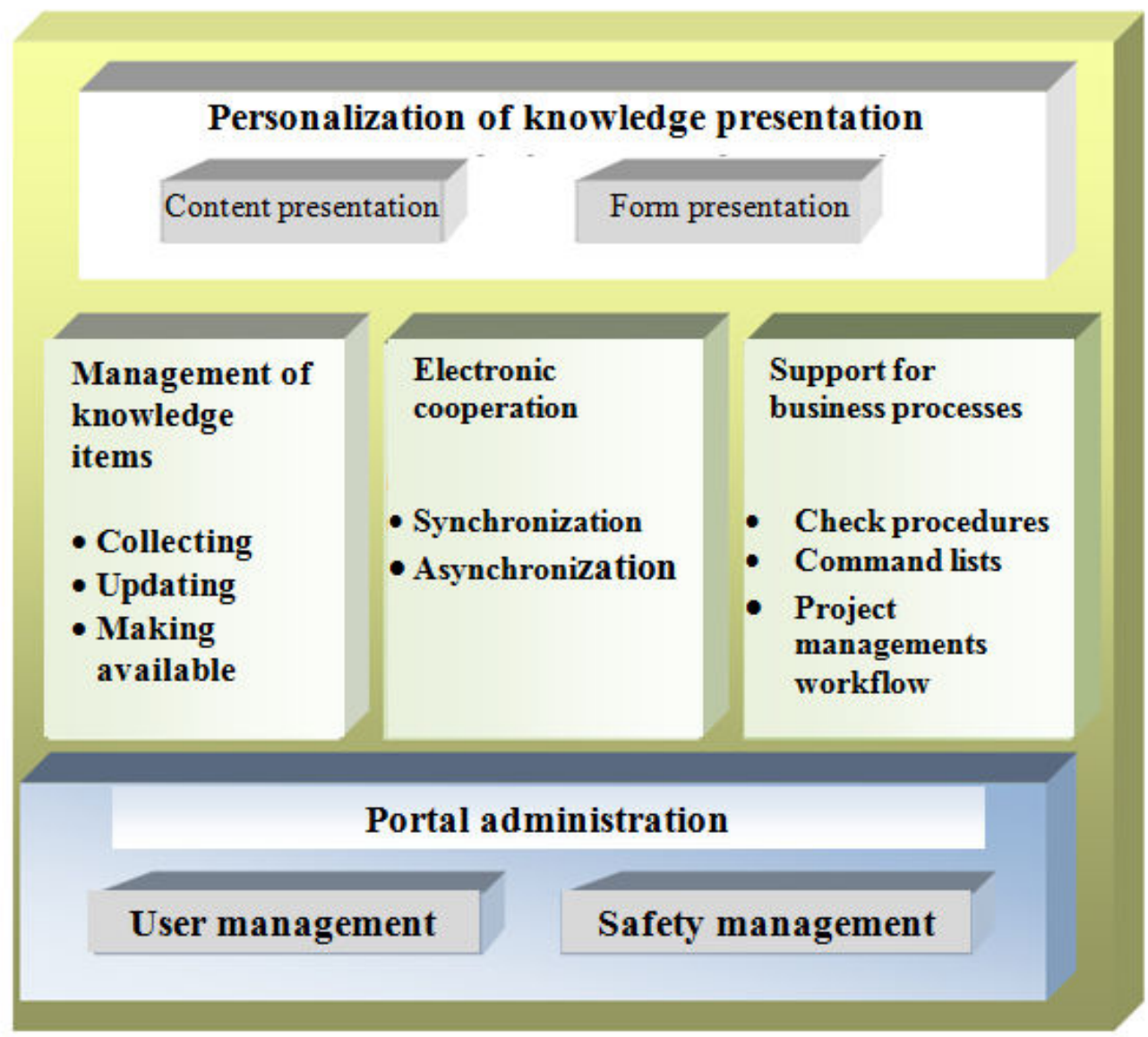

Fig. no 1- Functionality of Corporate Portal

Source: Goluchowski J.: Technologie informatyczne $w$ zarzadzaniu wiedza $w$ organizacji, Wydawnictwo Akademii Ekonomicznej im. K.. Adamieckiego w Katowicach, Katowice2005, s.187. cooperation.

Next group, electronic cooperation, encompasses synchronous and asynchronous electronic

Another group, concerning process support is characterized by functionalities of:

- workflow management,

- check procedures,

- command lists,

- project management,

- management of ad hoc projects (processes).

Last group is formed by portal administration and it encompasses: user and safety management.

In general, one can conclude that main task of corporate portal is multi-level integration and aggregation of business applications and information originating from different sources. Application of proper tools for content management, flow of information, (not only logistics-related but also other auxiliary information) and ensuring opportunities of direct interaction with selected processes comprises efficient logistics management in the company. It results from faster and more reliable communication between employees, partners, customers and suppliers, ensured by application of one user friendly interface, based on web browsers. 


\section{Needs and Responsibilities of Logistics Decision-Makers}

During the conducted investigations a scope of needs and responsibilities of logistics decision-makers was determined. These people should be perceived as persons who co-create strategies on the basis of the owned resources of logistics information and own preferences.

The tools for support of their work include interface, whose informational content extends current knowledge and allows for assessment of the consequences of the choices made.

Since the process of decision-making in terms of logistics management should encompass and harmonize all the logistics processes, i.e. procurement, production, inventory management, sales and should ensure coherence of the decisions made in other areas of functionality within a company, logistics decision-makers should have opportunity to determine [ Uwzględniono "pięć złotych reguł" zapobiegających bankructwom przedsiębiorstw, Burbridge J.L.: Five golden rules to avoid bankruptcy, Production Engineer nr 10, 1983, s. 12-14.]:

1. Number of products manufactured so that the marketing time was possibly shortest.

2. Production plan with possibly shortest manufacturing times.

3. Range of parts, details, subassemblies for a particular manufacturing times which will be used in next period.

4. Procurement level adapted to the size of current production, which considerably impacts on reduction in inventory costs.

5. Time of flow of all the goods (materials, raw materials, parts, semi-finished good, final products etc.) and information which is minimal, thus supporting production flow and prevents stoppages and bottlenecks.

Therefore, information which logistics decision-makers have to obtain concern:

1. Level of production and sales of goods and services adapted to the demand and limited by shortest marketing time.

2. Planning of production, sales and services for short periods of time, which, in consequence, leads to cost reduction and improved customers' satisfaction, especially in the case of rapid transitions in the environment.

3. Adaptation of the amount of the produced parts, purchased goods and investments in the investigated production period, sales of goods and services to reasonable demand and planned level of total consumption in next period.

4. Minimization of purchase of next materials, raw materials, production and commercial goods and investments in service providers, which satisfies only current operation.

5. Time of flow of all goods (materials, raw materials, parts, semi-finished goods, final products) and information in order to take necessary actions toward shortening this time.

\section{Intuitive Graphical Interface for Analysis of Logistics Information}

Fast, optimal access to the abovementioned logistics information and to applications supporting decision-makers' work is, in most of the investigated companies, difficult due to lack of integration of IT systems and common databases. In order to meet businesses' needs and to facilitate the process of decision-making in terms of logistics, the attempt to design an application for integration of business processes within the company and giving access to necessary logistics information in graphical form was made on the basis of internet-based ergonomic and easily accessible user interface. It should become a bridge between logistics decision-makers and the whole system or distributed software and applications. By means of properly designed interface, it is possible to achieve efficient communication with programs containing relevant logistics informational resources. Through flexible system of navigation, decision-makers have opportunities to select information both suggested by the interface and according to their own preferences consistent with the adopted procedures for choice of optimal solution. 
In order to create the interface, programming tool C\# Builder 2006 was employed, containing .Net 1.1 platform and TeeChart libraries, generating graphical presentation of necessary information. The software designed using $\mathrm{C \#}$ language are compiled to Common Intermedia Language (CIL), setting the role of intermediary code performed in runtime environment such as .NET, Mono or DotGNU. Due to the fact that the most frequently used software for documents creation is Microsoft Office XP package, it is necessary to install interoperational assemblies, known as Primary Interop Assemblies COM, available at http://www.microsoft.com/downloads/details.aspx?FamilyId=C41BD61E-3060-4F71-A6B4-

01FEBA508E52\&displaylang=en. These assemblies contain official description of the most common libraries for types in Microsoft Office XP package and facilitate cooperation of the managed .NET code with libraries of COM types in Office XP package, especially Microsoft Excel, the most popular among the employees. Using Microsoft Office 2003, installation of these assemblies is useless. A precondition for proper operation of the proposed interface is access to the selected graphical software and to all reports necessary during decision-making process, which are visualized in text or tabular form. It is not necessary for the application users to be fluent in use of the graphical software, since visualization process is performed without their participation and a ready graphical presentation is displayed on the screen, created automatically on the basis of the prepared models of particular types of logistics information. The user has also opportunity to select, according to their preferences, a type of graphical form of the presented information and modify the presentation adapted automatically to the analyst's needs. Publication of the automatically or 'manually' created graphical presentation of the information selected by users of information is possible through the generated XML files. Prototype of application for visualisation of logistics information from the reports delivered to the analysts by means of easily accessible and intuitive graphical user interface is presented in Fig. 2.

The figure presents the screenshot of main screen where users can access, on the left, menu containing information in the form of registers and reports, according to current needs and level of authorization. After selection of the document or a set of particular data, centre of the screen will display current document in tabular form and, after confirmation of the selected graphical form with the mouse click, next screen will show graphical presentation of the logistics information selected before (Fig. 2.a). Mouse click on a selected element of the chart, e.g. remuneration, allows for displaying of the value of cost types in a particular components, 'Remuneration' in this case (rys. 2.b). The application has easily accessible intuitive interface and was very popular among the employees in the investigated enterprises, however, problems that arose prevented it from being used on everyday's basis. The biggest hindrance was lack of access for analysts to electronic version of the delivered documents.

In over $80 \%$ of the investigated companies, analysts and decision-makers obtain necessary logistics information in paper form. This is connected with lack of integration between the modules of IT system and the distributed applications supporting logistics activities in companies.

Furthermore, the barriers which prevent from use of this type of application include:

- lack of internal networks which simplify communication between employees,

- lack of central database or data warehouses,

- lack of IT systems integrating organization's activity,

- lack of financial resources necessary for organizational restructuring and implementation of innovation facilitation internal and external communication, 
- habits and unwillingness of most of the employees and managers to implementation of any changes.

a)

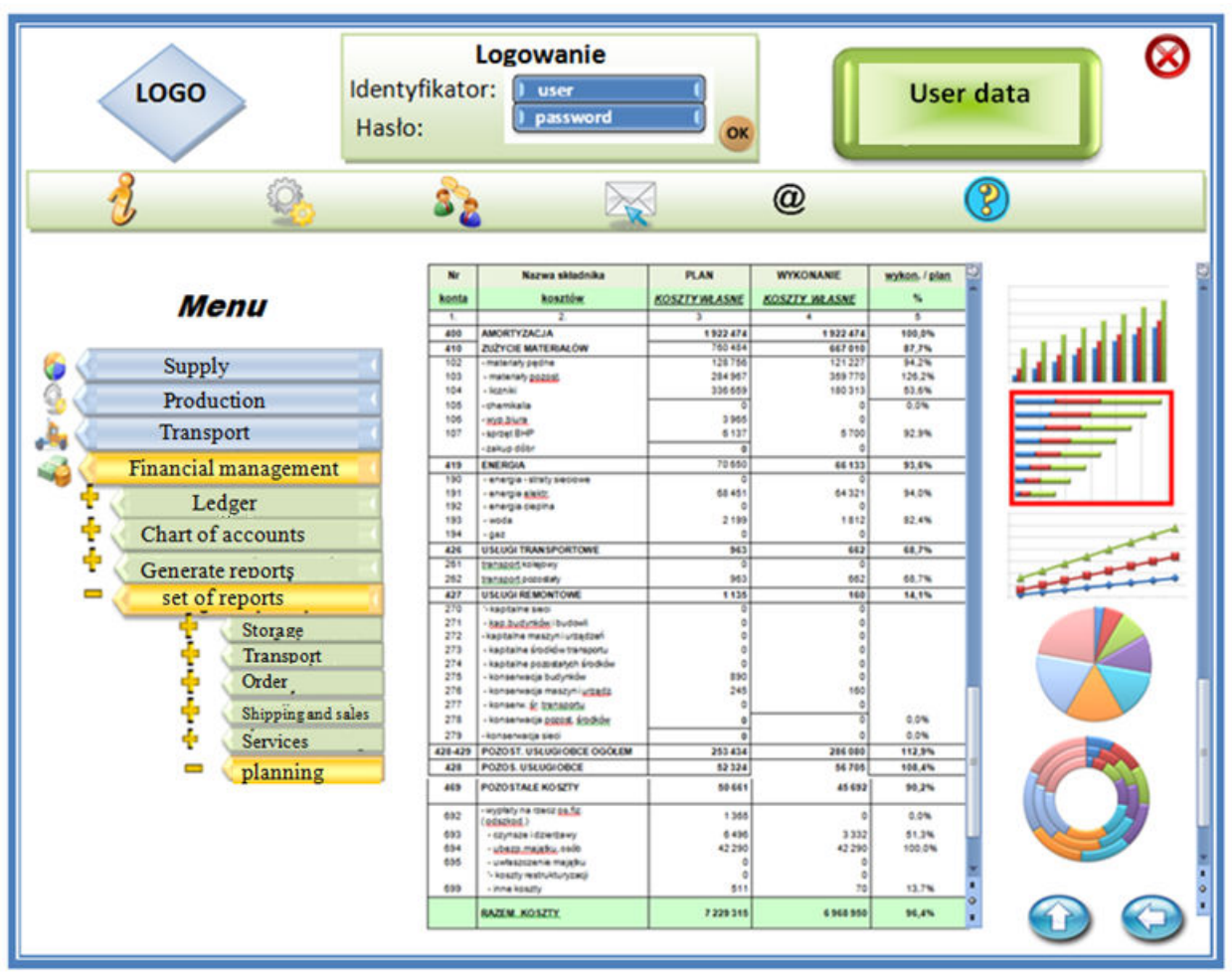

b)

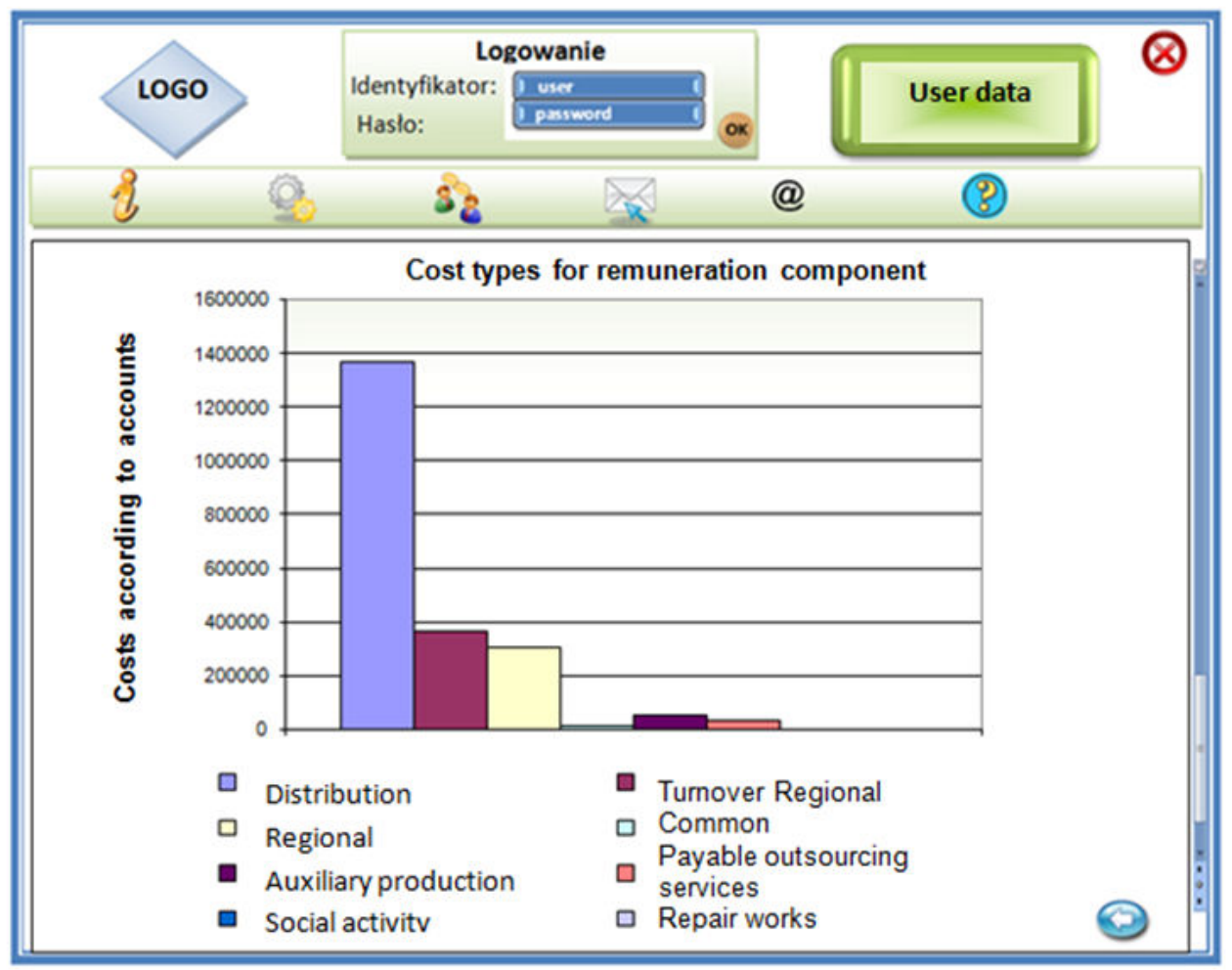

Fig. no. 2 - Consecutive screenshots of the interface for analysis of logistics information and decision-making through visualization of information 
In consideration of these difficulties to application of the tools which facilitate analysts' and decision-makers' work and high costs of purchase of conventional integrated IT system, and, additional fees connected with the implementation, training, service and modification in case of extension, an idea arose to search for solutions created on the basis of Open Source and using internet browsers. Because almost $100 \%$ of Polish companies have access to the Internet, which, according to the surveys' results, is almost unused for supporting of business activity, it seems to be logical to employ internet applications, made available through web browsers.

Interfaces making use of web browsers considerably differ from conventional applications which serve individual business processes. They are characterized by the following features (por. Dąbrowski W., Hryniów R, Pieciukiewicz T., 26.06.2008):

- dynamic changeability - implementation of continuous changes, both to functionalities of internet applications and to publicizing of information,

- scalability - allowing for use of internet applications through unlimited number of users in short time,

- navigation - due to the number of available information and necessity of using proper interaction, system of navigation in internet applications, unlike conventional ones, must be more extended, flexible, user friendly and efficient,

- intuitive, easily accessible user interface - although the opinion exists that interfaces in conventional applications are much more adapted to users' expectations, observation of development of internet tools which support their design reveals that differences between each other have long disappeared while interface functionality depends only on knowledge and skills of the designer,

- personalization - opportunity of adaptation of the presented content and the form of presentation and screens in application to users' preferences,

- easiness of use of internet applications - due to growing popularity of the Internet and some habits concerning operation of web browsers, internet applications do not require training for employees and they can intuitively make use of such software.

During design stages in development of logistics decision-maker interface, conventional visualization application was used for support of decision-making process. Advantages of optimal use of Internet and other internal networks in business activity will effectively break the barriers listed by the employees, which make it difficult to implement changes that would facilitate operation of the whole enterprise.

The design of the model of dynamic internet application which integrates business and administrative processes within a company, served by an interface enabling communication of all the co-workers and external users, is presented in Fig. 3.

Its main goal is to ensure integration of key logistics processes of sales, distribution, production, warehousing, procurement as well as accounting, finance and human resources management, both in the area of enterprise and its environment. The design of internet application contains distributed architecture and multilayer structure, which are inseparably connected by internet network. Such a structure allows for integration of all the applications and systems used within a company. The users perceive the application as a single software, characterized by such features as: scalability, dynamics, easiness of navigation between each category of information available in terms of the form and the content according to previously defined user's preferences and its role for the organization.

Multilayer application, mainly in the form of three-layer application, due to opportunity of extension of each layer, is typically referred to as a n-layer application. It is a modification of twolayer application of client/server, where intermediary layer containing elements of IT structure was separated. 


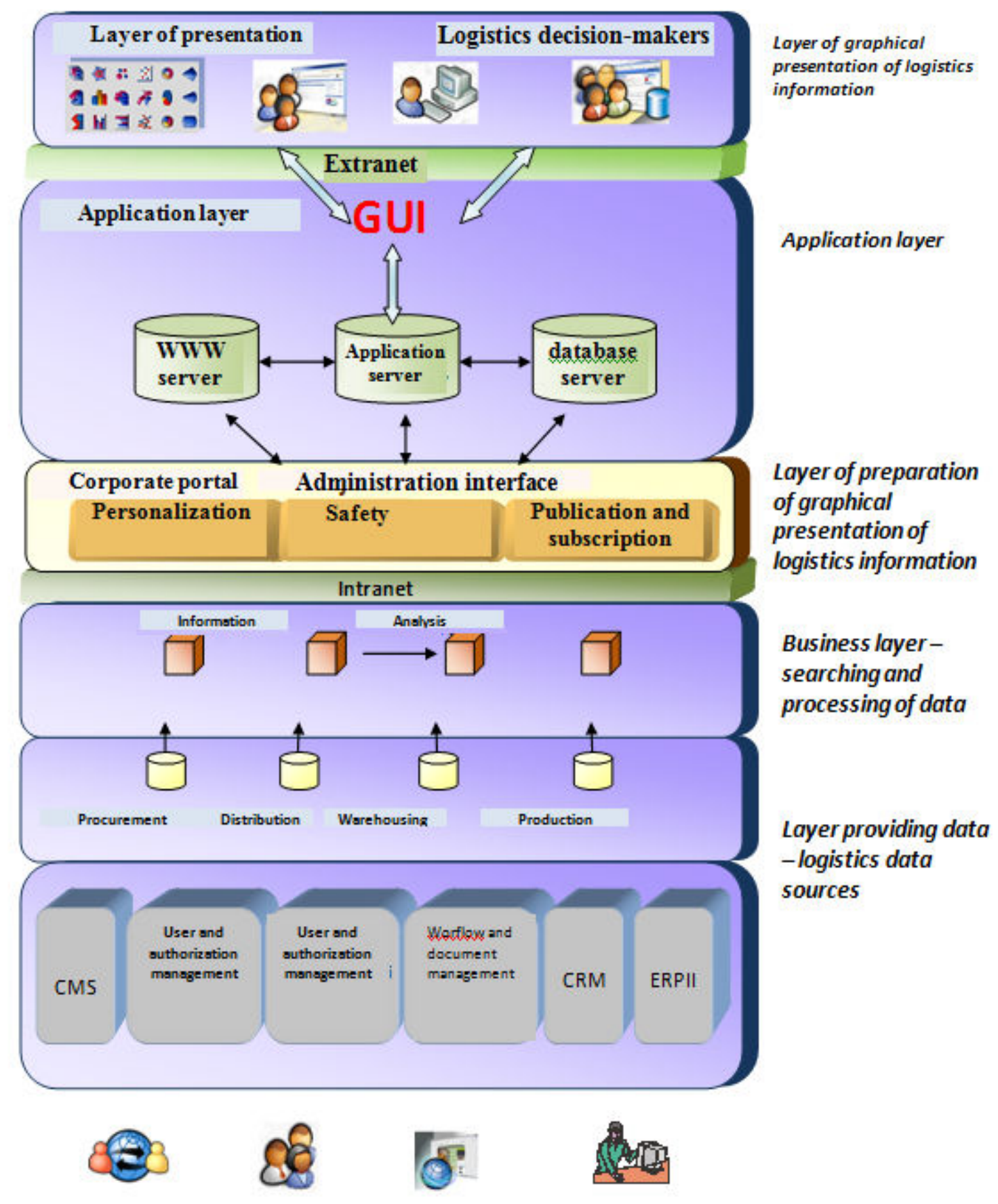

External customers: partners, suppliers, customers

Fig. no. 3 - Design of dynamic internet application for integration of internal logistics processes with the environment

Source: own study

A fundamental goal of multilayer architecture is to separate, from each other: presentation of information, functional logics, storage and management of information and access to information. Use of intermediary layer causes that internet application should be perceived as at least three-layer application.

The proposed design of dynamic internet application was created for all the businesses which make use of conventional applications without possibility of their integration. An overriding 
goal of the presented model was integration of all the logistics processes in order to get access to information about e.g. sales figures, amounts of available materials and goods, reservations and orders, financial transactions with customers and business partners and provision of complex business services. Multilayer structure and distributed architecture causes that this integration, although flexible for customers, allows for fast modification of application as a response to changes in business expectations. The information obtained in this way is reliable and, through application of their visualization, are becoming more transparent and clear for users, which simplifies the process of planning, forecasting and realization of logistics activities and, in consequence, increases efficiency of supply chain management.

\section{Personalization of Portals as a Tool for Adaptation of the Interface to the Logistics Decision-Makers' Needs}

In order to meet the needs for easier adaptation of the interface to the logistics decisionmaker's needs, a concept of personalization of corporate portals appeared. The tools for personalization of portals provide logistics decision-maker with opportunities of content and form adaptation.

Since personalization allows for adaptation of communication to a particular consumer, i.e. providing them with the expected information in right time and to right user through one, easily accessible interface, it should be adapted so that users, depending on the level of authorization, and thus on their role for organization and type of the decision being made, have access to a particular information resources, regardless the type of used applications and documents.

The greatest priority for personalization of internet applications is to satisfy users through dynamically providing them with the expected contents and products (webpages, recommendations, documents, information etc.) on the basis of a predetermined characteristics. Due to this fact, the process of personalization should be realized in a modern way by means of relevant techniques and mechanisms, unlike previous static methods of internet application adaptation.

Properties typical of modern process of personalization include (Stawarz T., 1, 05.04.2008):

- dynamics - this feature distinguishes between personalization and other methods of adaptation of the offered products, consisting in response to users' actions in real time through analysis of the selected hyperlinks or implementation of the analysis of mouse cursor position

- intelligence - application of technologies of knowledge acquisition,

- automaticity - transfer of responsibility for adaptation of products' presentation from users to server.

During the process of personalization one should use all the possible mechanisms for facilitation and simplification of 'personalization cycle', which encompasses the following tasks (Gołuchowski J., Filipczyk B., Jabłońska M., 2007, s.49-57.):

- searching, collecting and continuous updating of the knowledge of users,

- planning of methods of contacting users on the basis of the acquired knowledge about users,

- regular contact with users in order to extend the knowledge about them.

During the process of personalization, it is advisable to adapt mechanisms which determine the model of user and the recommender systems. The model of user describes particular aspects of the user interacting with the system, i.e. depending on the domain of application, it collects information about users' preferences, goals and demand. Recommender systems, using technologies of information filtering select and present, from a huge space of possible options, the information which is relevant to the users' needs (Chen Y. S., Magoulas G. D., 05.04.2008). It is remarkable that information filtering does not necessarily have to be based on a created model of user. The model, on the other hand, does not have to be fixed, since the view of users might be expressed by their current needs and the view of previous users with similar preferences. 
In the case of the model of the process of personalization presented below, in order to obtained better and faster effects, a combination of such techniques as: content based filtering, collaborative filtering, rule based filtering and Web mining was used.

Fig. 4 presents the model of the process of personalization with consideration of fundamental modules and location of each technique.

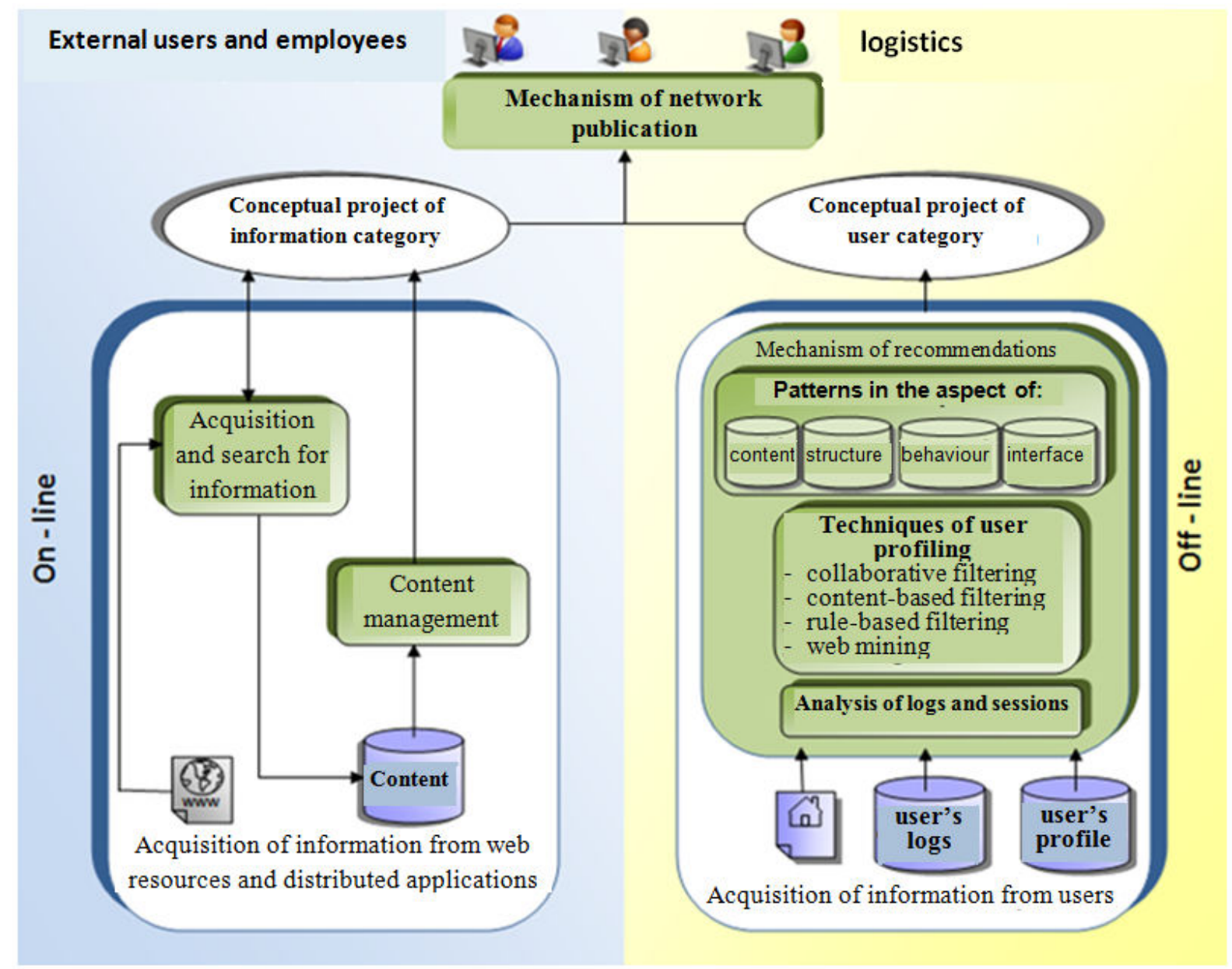

Fig. no. 4 - Model of personalization process

Source: own study on the basis of: Magdalini E., Vazirgiannis M.: Web Mining for Web Personalization; Communications of the ACM, Vol. 3, No. 1, February 2003, s.5, http://portal.acm.org/citation.cfm?id - 09.04.2008.

During first stage of the process, periodical extraction of all the possible patterns for user categories occurs, through off-line module, as a result of the analysis of logs from servers and comparison of users' characteristics on the basis of the acquired knowledge about them. Next stages must be realized in real time by on-line module in order to determine the categories of information adequate to categories of users. The best correlated objects, originating from on-line and off-line modules, are presented within the network through the mechanism of publication. Fundamental areas encompassed by personalization include: content, presentation form and navigation.

Personalization brings great opportunities for all users of corporate portals. For businesses which own a functional corporate portal, which allows for modern personalization of a uniform, ergonomic interface designed for a group of employees fulfilling particular roles, for individual employees and all co-workers and customers this mainly means improvement in communication and integration of a number of dispersed tools, business applications and systems, with high quality 
of relationships within organizational structure. This simplifies access to structural and ordered information resources and thus to bigger amount of the used knowledge. Through advanced functionality of the portal, such as videoconferencing, message boards, virtual rooms for cooperation it is possible to share and exchange knowledge by means of cooperation of employees, partners and customers, which is essential for complex logistics management and participation in integrated supply chains. It also involves fast decision-making at all organizational levels, ensuring measureable benefits, e.g. cost reduction or profit generation. Optimal use of functionalities of corporate portal also contributes to rise in employee's productivity.

Fundamental advantages which bring benefits to the owners of personalized corporate portals include:

- time effectiveness and reduction of costs connected with integration of software and implementation of new applications,

- facilitation of business and organizational processes through integration of a variety of applications and data from relational, transactional and network-related databases and extended systems of planning,

- opportunity of defining of target group of employees, wholesale customers, contractors, individual customers,

- great opportunities of efficient communication between the employees in an organization and between the company and contractors and customers.

- increased productivity and efficiency of employees,

- extended organizational knowledge,

- advantage over competitors,

- efficient business transactions,

- safety of the content and tools made available within the portal.

According to the investigations, there is a need among employees for easily accessible dynamic internet applications which integrate all the areas of company's activity in order to realize optimal logistics management. User friendly, intuitive interface for these programs come in to great help. Figure 5 presents the model of graphical user interface for optimization of logistics information visualization in order to simplify work of analysts and logistics decision-makers.

The presented model shows module-based structure, which allows for easy modification of components if the need arises. According to the consecutive procedures, users, after logging in and entering the password, are granted the access to reports displayed on the left of the screen, accordingly to the level of authorization defined by the administrator. After selection of the requested documents, their content is displayed in the source form. Next, after confirmation of the visualization, the content of the whole report or the selected items are automatically displayed in next screen in the form of chart. The users can, according to their own needs, modify the displayed screen or to create it by selection of graphical components seen on the right of the screen. The analysis of the obtained chart allows for, through clicking on its individual components, tracking of their levels and sources. This methods enables tracking of e.g. the process of cost generation in the area of procurement, which was carried out in three companies selected from all the investigated businesses. There is also a possibility to compare their levels from different periods of activity, but the access to informational resources collected in databases integrated with the interface is necessary. 


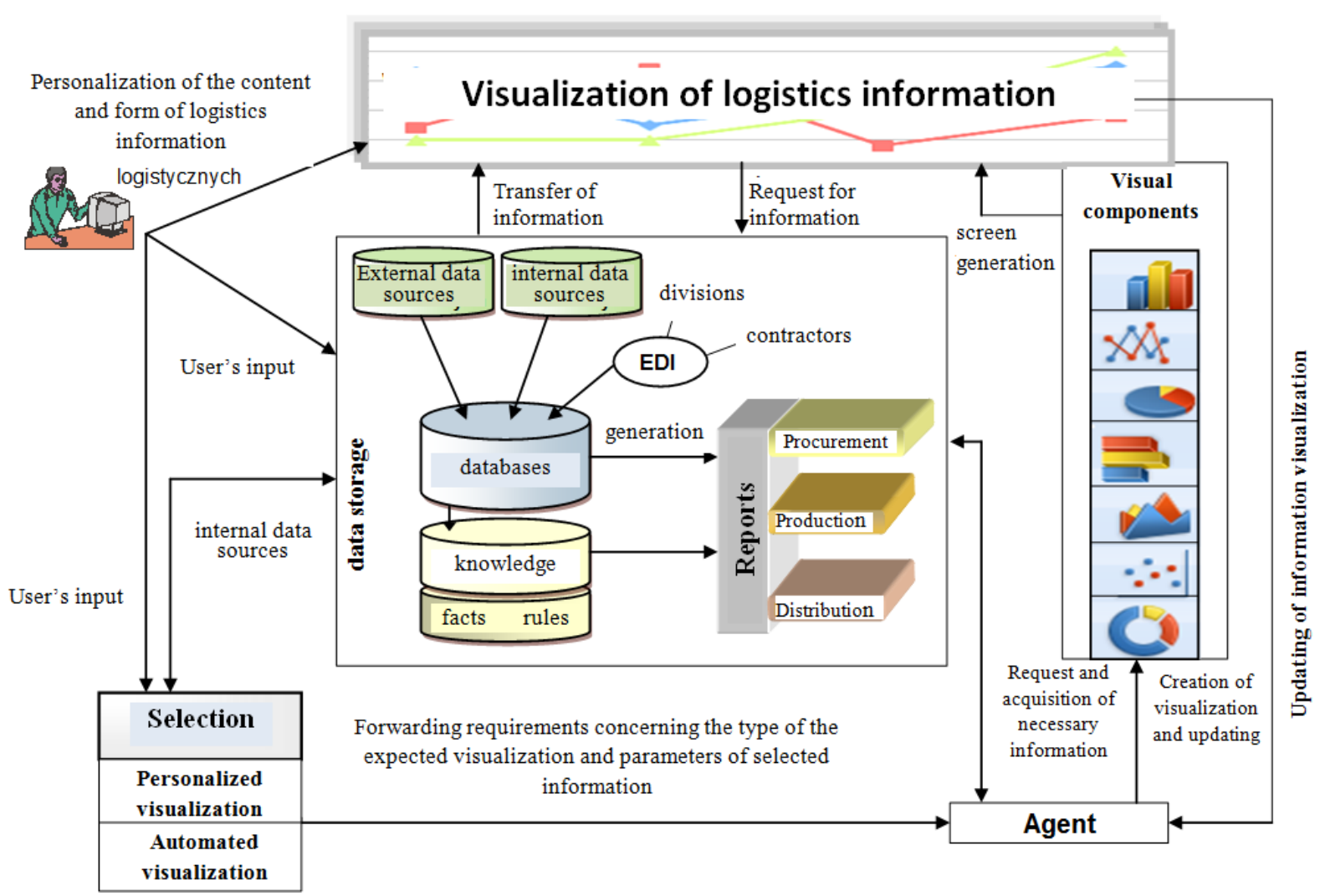

Fig. no. 5 - The model of graphical interface for visualization of logistics information for logistics decision-makers

Source: own study

Properly functioning interface should operate in relation to the system of navigation, locating the objects with hyperlinks to the documents interesting for the users. The proposed prototype of the model of logistics information visualization should be tested among larger number of users in the environment of IT system integrated in the area of logistics, which would provide precious experience and would contribute to modification of current model towards a perfect, in terms of simplicity of use, speed and efficiency, tool for visualization of logistics information.

Use of interface designed as a dynamic internet application for support of logistics decisionmaking will ensure: information,

- enhanced speed of flow of information and access to necessary and valuable

- presentation of information in a way adapted to human abilities of perception,

- creation of databases (data warehouses) with opportunity of general access to its content,

- clarity and transparency of individual logistics processes, which will accelerate analytical and decision-making processes at each level of management,

- fast access to systems and programs for support of analytical and decision-making processes,

- fast access to knowledge bases, models and patterns to support the speed of decision making and to verify the knowledge and adequateness of the decisions.

\section{Conclusions}

On the basis of the results of the investigations one can conclude that, despite development of IT technologies, IT tools are steel treated as a tool for automation of company's operation, 
particularly its operational processes. The focus should also be on the change in the methods of operation towards integrated IT systems and process management. Therefore the need arises to provide organizations with inexpensive and efficient applications which integrate all the internal logistics processes and improve communication between employees, contractors, customers and the whole environment which provides valuable information simplifying realization of the processes of decision making.

Business organizations which want to stand chances to fight competitors and to cooperate with the best, should strive for integration of logistics IT systems that have impact on the strategy of operation, manifested in assessment of the enterprise position in the market and in selection and implementation of the concepts of operations which ensure its profitable and oriented development. The biggest challenge for the future should be a conviction of necessity of solutions for company's integration and mobilizing workers towards commitment to its development through doing their duties, willingness to deepen and ability to share the knowledge. The solutions are provided by corporate portals which ensure realization of fundamental logistics goals, i.e. coordination of the flow of materials, raw materials and final products to consumers, minimization of costs of such flows, conforming logistics operation to customer service's expectations and striving for logistics knowledge-based management. Efficient use of all functionalities within portals for support of logistics business and organizational processes and continuous development of these processes will contribute to creation of intelligent systems of knowledge management, whose quality will determine the future of each organization.

\section{References:}

1. Burbridge J.L., Five golden rules to avoid bankruptcy, Production Engineer 1983 nr 10;

2. Chen Y. S., Magoulas G. D., 2005, Adaptable and Adaptive Hypermedia Systems, IRM Press, 2005 - http://books.google.com/, 05.04.2008;

3. Chen Y. S., Magoulas G. D., 2005, Adaptable and Adaptive Hypermedia Systems, IRM Press, 2005 - http://books.google.com/, 05.04.2008;

4. Dąbrowski W., Hryniów R, Pieciukiewicz T..: Metody projektowania aplikacji internetowych, www.si.pjwstk.edu.pl/publications/papers/KKIO2004MetodykiProjektowaniaEAplikacji.pdf 26.06.2008;

5. Gołuchowski J., Filipczyk B., Jabłonska M., 2007, ECommerce Applications Design, Wyd.AE Katowice, Katowice;

6. Gołuchowski J., 2005, Technologie informatyczne w zarządzaniu wiedzą w organizacji, Wydawnictwo Akademii Ekonomicznej im. K.Adamieckiego w Katowicach, Katowice;

7. Kisielnicki J., 2008, Zarządzanie. Jak zarządzać i być zarządzanym. Polskie Wydawnictwo Ekonomiczne, Warszawa;

8. Małachowski A. (red.), 2003, Internet w zarządzaniu przedsiębiorstwem, Wyd. Akademii Ekonomicznej im. Oskara Langego, Wrocław;

9. Pańkowska M., Sroka H (red.), 2002, Systemy informatyczne organizacji wirtualnych, Wyd. Akademii Ekonomicznej im.K.Adamieckiego w Katowicach, Katowice;

10. Stawarz T., Teoretyczne podstawy adaptacyjnych stron, techniki odkrywania wiedzy do ich personalizacji, http://www.klubinformatyka.pl/artykul.php?a=8\&s=1, 05.04.2008. 